\title{
Primary cold agglutinin-associated lymphoproliferative disease: a B-cell lymphoma of the bone marrow distinct from lymphoplasmacytic lymphoma
}

\author{
Ulla Randen ${ }^{1,2}$, Gunhild Trøen, ${ }^{1}$ Anne Tierens, ${ }^{1}$ Chloé Steen, ${ }^{1}$ Abdirashid Warsame,,${ }^{1,2}$ Klaus Beiske,${ }^{1}$ Geir E. Tjønnfjord, ${ }^{2,3}$ \\ Sigbjørn Berentsen, ${ }^{4,5}$ and Jan Delabie ${ }^{1,2}$
}

${ }^{1}$ Dept. of Pathology, Oslo University Hospital; ${ }^{2}$ Institute for Clinical Medicine, University of Oslo; ${ }^{3}$ Dept. of Hematology, Oslo University Hospital; ${ }^{4}$ Dept. of Medicine, Haugesund Hospital, Haugesund; and ${ }^{5}$ Institute of Internal Medicine, University of Bergen, Norway

Primary chronic cold agglutinin disease is a rare hemolytic disease mediated by monoclonal IGHV4-34-encoded cold agglutinins with a predominant specificity for the blood group antigen I. Bone marrow from 54 patients was studied to type the underlying lymphoproliferative disorder better. Bone marrow biopsies showed circumscribed intraparenchymatous nodules with small monotonous monoclonal B cells in 40/54 patients (median infiltration: 10\% of marrow cells) with a CD20 $0^{+} \mathrm{IgMs}^{+}, \mathrm{IgDs}^{+}, \mathrm{CD}_{27^{+}}, \mathrm{CD}^{-1+}, \mathrm{CD}^{1} \mathrm{c}^{-}, \mathrm{CD} 23^{-}, \mathrm{CD} 38^{-}$immunophenotype. Neither plasmacytoid cytological features nor expression of plasma cell differentiation-associated transcription factors MUM1, XBP1 and BLIMP1 were noted in these B cells. However, a limited number of mature monoclonal IgM+' IgD- plasma cells were present outside the lymphoid nodules and were diffusely scattered throughout the marrow. Of interest, the MYD88 L265P mutation, typical of lymphoplasmacytic lymphoma, was not detected (17/17 cases). Somatically mutated monoclonal IGHV4-34 gene rearrangement was demonstrated in eight patients with frozen samples (mean sequence homology 95.4\%). However, mutations of BCL6 intron 1 were not demonstrated, except in one patient, suggesting that the lymphoma cells had not matured in the germinal center. In conclusion, cold agglutinin-associated lymphoproliferative disease displays homogeneous histological and immunophenotypic features. The absence of plasmacytoid cells, the presence of plasma cells predominantly outside the nodular lymphoid infiltrates, IGHV4-34 restriction and absence of MYD88 L265P mutation strongly suggest that cold agglutinin-associated lymphoproliferative disease is a distinct entity that is different from lymphoplasmacytic lymphoma.

\section{Introduction}

Primary chronic cold agglutinin disease (CAD) accounts for about $15 \%$ of all cases of autoimmune hemolytic anemia. ${ }^{1-5}$ The incidence has been estimated to be $1 / 10^{6}$ per year., ${ }^{6,7}$ Anemia results from binding of monoclonal cold agglutinins, most often IgM with $\kappa$ light chains, to the I antigen on the erythrocyte surface. Bound immunoglobulins cause red blood cell agglutination and complement activation, leading to phagocytosis of complement-coated red blood cells by the reticulo-endothelial system. ${ }^{4,8}$ About $50 \%$ of patients become transfusion-dependent. The diagnosis of CAD requires a cold agglutinin titer of $\geq 64$ and a positive polyspecific as well as a C3d complement protein monospecific direct antiglobulin test. ${ }^{5}$ The agglutinin titer varies greatly among patients with values as low as 64 to over $500000 .^{9}$ However, the thermal amplitude, defined as the highest temperature at which the antibody binds to red blood cells, is more directly associated with clinical hemolysis than is the titer. ${ }^{2,9}$ The ratio of IgM antibodies that occur as pentamers or hexamers, the latter of which activate complement more easily, also determines the severity of the anemia..$^{10,11}$ The immunoglobulin heavy chain of anti-I agglutinins is typically encoded by the IGHV4-34 gene segment. The latter is required for binding to I-antigen on red blood cells. ${ }^{12}$ More specifically, the IGHV4-34 framework region 1 (FR1) is mainly responsible for I-antigen binding. ${ }^{13}$

CAD has previously been associated with underlying B-cell lymphoproliferative disease in up to $75 \%$ of patients, with lymphoplasmacytic lymphoma being the most common diagnosis. ${ }^{6}$ The demonstration of underlying B-cell lymphoproliferative disease provided the rationale for treatment with rituximab, either as monotherapy or, with better responses, in combination with fludarabine therapy. ${ }^{14,15}$

We reviewed morphological and immunophenotypic findings in bone marrow biopsies and aspirates from 54 patients with CAD to critically reappraise the underlying lymphoproliferative disease. To further characterize the cell of origin we analyzed somatic hypermutations of the rearranged immunoglobulin heavy chain gene as well as the BCL6 gene. Additionally, we screened for the MYD88 L265P mutation, known to be strongly associated with lymphoplasmacytic lymphoma. ${ }^{16,17}$

\section{Methods}

\section{Patients}

Fifty-four patients with clinically well-documented primary 
CAD diagnosed in the time period between 1995 and 2012 were studied. There were 36 women and 18 men with an age range of 40-92 (median 73) years. All patients had a clinical history of CAD with a variable degree of anemia, a positive C3d-specific direct antiglobulin test and a cold agglutinin titer in excess of 64. Monoclonal IgM had been detected in the serum of all patients by agarose electrophoresis and immunofixation. None of the patients had lymphadenopathy or splenomegaly. Clinical follow-up ranged from 3 to 152 months, with a median follow-up of 72 months.

The study was approved by the institutional and regional ethical committees.

\section{Biopsy material}

Archival hematoxylin and eosin-stained sections of bone marrow trephine biopsies from the 54 patients, obtained at diagnosis, were reviewed. Fourteen biopsies were fixed in $4 \%$ formaldehyde, 18 in Bplus fixative and 22 in B5 fixative. In addition, part of the diagnostic trephine biopsy of eight patients had been snap-frozen in liquid nitrogen. Two of the patients had undergone splenectomy in an attempt to reduce hemolysis. Hematoxylin and eosin-stained archival sections of formalin-fixed splenic tissue of these patients were reviewed.

\section{Immunohistochemistry}

Immunohistochemical analysis was extended or repeated whenever archival sections were not available or of bad quality. The primary antibodies and the method used for immunohistochemical analysis of the bone marrow trephine biopsies are described in the Online Supplementary Methods.

\section{Flow cytometry}

Flow cytometry was performed on samples from 25 patients and included a total of 46 bone marrow and 10 paired peripheral blood samples, anticoagulated with heparin and EDTA, respectively. On samples analyzed before 2011, a four-color analysis ${ }^{18}$ and from 2011 onwards, an eight-color analysis ${ }^{19}$ was performed with antibody combinations as described in the Online Supplementary Methods.

\section{Immunoglobulin heavy chain gene sequencing, and BCL6 and MYD88 mutation analyses}

DNA was extracted from frozen bone marrow trephine samples, obtained from eight patients, using the EZ1 tissue kit (Qiagen, Hilden, Germany) and from formaldehyde-fixed paraffin embedded-tissue sections from another nine patients using the OIAamp DNA FFPE tissue kit (Qiagen). Immunoglobulin heavy chain gene analysis and $B C L 6$ intron 1 mutation analysis was only performed on DNA from frozen tissue samples whereas MYD 88 mutation analysis, requiring less intact DNA, was performed on frozen and formaldehyde-fixed tissue samples.

$B C L 6$ intron 1 was amplified using three sets of overlapping polymerase chain reaction (PCR) primers covering nucleotides 24 to 790 in GenBank sequence AF191831. The primer pairs and PCR conditions are described in the Online Supplementary Methods. PCR products were sequenced and analyzed using the BLAST database.

The MYD88 L265P mutation (NM_002468) was analyzed using PCR and a SNaPshot multiplex kit (Applied Biosystems). PCR primers and conditions are described in the Online Supplementary Methods. A series of 47 fixed bone marrow trephine biopsies of patients with well-documented lymphoplasmacytic lymphoma was used for control purposes.

\section{Results}

\section{Follow-up of patients}

Eighteen patients were alive as of December 31 2012, without relevant co-morbidity, whereas 12 patients had died. Twenty-four patients were eventually treated at other hospitals and no clinical follow-up information is available. None of the patients was diagnosed with extramedullary lymphoma or developed extra-medullary lymphoma in the course of their disease. Of the 12 patients who died, three died with malignant disease (melanoma, ovarian cancer and acute lymphoblastic leukemia), one patient died with sepsis whereas eight patients died of unknown cause.

\section{Bone marrow pathology}

Lymphoid infiltration consisting of nodular B-cell aggregates was seen in the marrow of 40 patients. In contrast, 14 patients showed only few and scattered B cells. In the former patients, lymphoid infiltration varied between $5 \%$ and $80 \%$ of the intertrabecular surface, with a median of $10 \%$. Infiltration was nodular (Figure 1A-D) and consisted of small-sized cells with round to slightly oval nuclei without a discernable chromatin pattern (Figure 1E and 1F). The cells contained a small amount of clear cytoplasm. A few scattered histiocytes were admixed with the lymphoid cells. Mature plasma cells were seen surrounding the lymphoid aggregates but were invariably also seen throughout the marrow between the nodular lymphoid aggregates (Figure $1 \mathrm{G}$ and $1 \mathrm{H}$ ). Of interest, only few plasma cells were seen within the nodular lymphoid aggregates (Figure 1G). Plasma cells were not abundant and represented less than $5 \%$ (range, $2-10 \%$ ) of nucleated cells in the marrow. Of note, features associated with lymphoplasmacytic lymphoma such as paratrabecular growth, fibrosis, lymphoplasmacytoid cell morphology or an increased number of mast cells surrounding the lymphoid aggregates were not seen (Online Supplementary Figure S1).

To investigate whether a correlation existed between the number of lymphoid aggregates in the bone marrow and hemoglobin concentration, the Spearman rank order correlation coefficient $\left(r_{s}\right)$ was calculated. The $r_{s}$ was -0.24 , indicating only a very weak negative correlation between the extent of marrow lymphoid infiltration and hemoglobin concentration (Online Supplementary Table S1).

\section{Spleen histology}

Review of the records revealed only a partial description of the splenectomy specimens obtained in two patients. The spleen of one patient measured $13 \times 11 \times 7 \mathrm{~cm}$, but no weight was recorded. The spleen of the second patient weighed 540 grams without a further description of the specimen in the records. Upon review, the histology showed a similar morphology. The red pulp was histologically unremarkable. Scattered plasma cells were noted, but these were not exceptionally numerous. Of note, no abnormal lymphoid infiltration was noted (Figure 2A). The white pulp was hypoplastic and showed periarterio- 


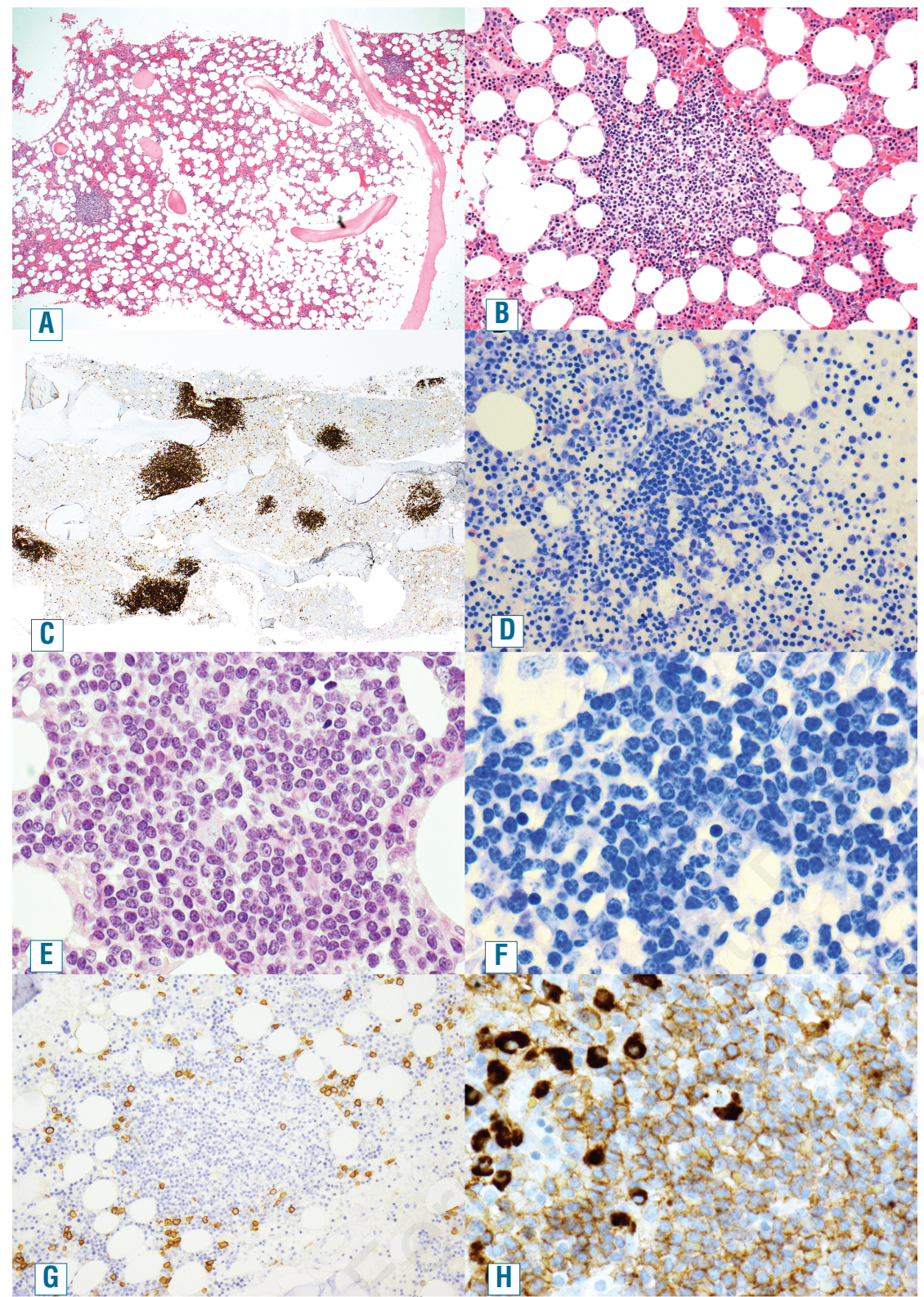

Figure 1. The figure illustrates the bone marrow histology in CAD-associated lymphoproliferative disease. A bone marrow trephine biopsy showing intraparenchymatous nodular lymphoid lesions (panels (A) and (B), H\&E-staining, 40X and 200X, respectively). Immunoperoxidase staining for CD20 highlights intraparenchymatous nodular B-cell infiltration (panel (C), 200X). Mast cells are not usually discerned around the nodular lymphoid lesions [panel (D) Giemsa-staining, 200X]. High magnification shows small lymphoid cells with rounded nuclei without prominent nucleoli [panels $(E)$ and $(F), H \& E$ staining, 400X and Giemsa staining, $600 X$, respectively]. Scarce plasma cells surround the lymphoid nodules but are also found diffusely within the parenchyma [panel (G), anti-CD138 peroxidase staining, 100X]. The lymphoid cells express membranous IgM and plasma cells express cytoplasmic IgM [panel (H), anti-IgM peroxidase staining, $400 \mathrm{X}]$.

lar sheets and marginal zones with small lymphoid cells (Figure 2A and 2B). Lymphoid follicles were absent.

\section{Immunophenotypic analysis}

The lymphoid cells within the lymphoid aggregates in the bone marrow trephine biopsies were mainly B cells interspersed with a few scattered $\mathrm{T}$ cells (Figure $3 \mathrm{~A}$ and 3B). These lymphoid aggregates were surrounded by IgMand IgK-expressing plasma cells (Figure 3C-E) that were also observed scattered throughout the marrow. B cells expressed nuclear CD20, PAX5, BCL10 (weakly), but not BCL6, XBP1, MUM1 or BLIMP1 (Figure 3F-H). B cells showed the following extended immunophenotype: $\mathrm{CD}^{+}{ }^{+}, \mathrm{CD}_{20}{ }^{\text {bright+ }}, \mathrm{CD} 79 b^{\text {bright+ }}, \mathrm{CD}^{2} 2^{+}, \mathrm{FMC}^{+}, \mathrm{IgM}^{\text {dim+ }}$, immunoglobulin $\kappa$ light chain ${ }^{+}(90 \%$ of cases), immunoglobulin $\lambda$ light chain (10\% of cases), $\mathrm{CD}^{+}(11 / 26$ cases), $\mathrm{CD}_{27}{ }^{+}, \mathrm{CD}_{4} 3^{\mathrm{dim}+}, \mathrm{CD} 200^{+}, \mathrm{CD} 10^{-}, \mathrm{CD} 11 c^{-}, \mathrm{CD} 21^{-}$, $\mathrm{CD}^{-} 3^{-}, \mathrm{CD}_{25}^{-}$, cyclin $\mathrm{D}^{-}$. Only a few cases were
CD11c dimt and CD25+. Of interest, all four of the 14 patients without abnormal lymphoid infiltration on histological examination showed monoclonal B cells by flow cytometry of the bone marrow. In the ten patients for whom flow cytometry of blood was also performed, monoclonal B cells with an identical immunophenotype to that seen in the bone marrow were detected.

Plasma cells in the red pulp of the spleen in two of the patients expressed predominantly, but not exclusively, IgM and IgK (Figure 2C and 2D). Marginal zone cells in the white pulp showed no obvious restricted immunoglobulin light chain expression (Figure $2 \mathrm{C}$ and $2 \mathrm{D}$ ). Infiltrating $\mathrm{T}$ cells were mainly $\mathrm{CD}^{+}$(Figure 3I and 3J).

\section{Immunoglobulin heavy chain gene analysis}

Full-length rearranged $\mathrm{IgH}$ variable region analysis was only possible using snap-frozen bone marrow biopsies obtained before treatment in eight patients since these 
samples contained non-degraded DNA. Monoclonal IGHV4-34 gene rearrangement was demonstrated in samples from all eight patients. Sequence analysis revealed 92.5 to $98.3 \%$ homology to the closest germ line IGHV434-1 sequence (Table 1, GenBank sequence numbers KC581946 to KC581953). Non-polar hydrophobic amino acid residues in positions 7 (tryptophan), 23 (alanine) and 24 (valine) as well as the polar hydrophilic amino acid in position 25 (tyrosine) of FR1 were conserved and not affected by somatic hypermutation. IgH CDR3 region length varied between 13 and 29 amino-acids (median, 15). Two of the patients showed an identical CDR3 amino-acid sequence, which was confirmed by repeated DNA extraction and sequence analysis. The CDR3 regions were characterized by several non-polar amino acids such as proline, glycine and isoleucine and polar amino acids such as serine (Table 1). Few positively charged amino acids were seen, as reported previously. ${ }^{12,20}$

\section{BCL6 and MYD88 mutation analysis}

$B C L 6$ gene intron 1 mutation analysis was performed in the eight cases with frozen tissue samples. One of eight cases showed three somatic mutations of the BCL6 gene (Table 1, GenBank sequence number KC581954). Mutations were not detected in the other seven cases.

The MYD88 L265P mutation analysis was performed on DNA from the eight cases with frozen samples as well as nine cases with only formalin-fixed paraffin-embedded trephine biopsies that showed more than 5\% lymphoid infiltration. None of the samples showed the MYD 88 L265P mutation. By contrast, MYD88 L265P mutation was demonstrated in fixed and paraffin-embedded bone marrow trephine biopsies in 45 out of 47 cases with lymphoplasmacytic lymphoma.

\section{Discussion}

The 54 patients in this study fulfilled the clinical criteria for primary CAD. Patients did not have lymphadenopathy, splenomegaly or any other clinical signs of lymphoma at the time of diagnosis. Notwithstanding, 40 out of the 54 patients showed abnormal lymphoid infiltration in the bone marrow which consisted of a variable number of well-circumscribed nodules of small lymphoid cells with a small amount of clear cytoplasm. These cells expressed CD19, CD20, CD22, CD79b, FMC7, mostly immunoglobulin $\kappa$ light chain, IgM, IgD, CD27 and only occasionally CD11c and CD25 but not CD23. Expression of CD5 was seen in less than half of the cases. These histological and immunophenotypic findings are reminiscent of those seen in bone marrow infiltration by extranodal or nodal marginal zone lymphoma. ${ }^{22}$ However, none of the patients showed evidence of extramedullary disease, excluding the diagnosis of marginal zone lymphoma. Intrasinusoidal infiltration, frequently present in splenic marginal zone lymphoma, was not seen in patients with CAD. In addition, scattered monotypic IgM-expressing plasma cells were diffusely spread in the bone marrow parenchyma and were slightly more numerous in the area surrounding the nodular lymphoid aggregates, findings not typical of marginal zone lymphoma. The presence of plasma cells is reminiscent of lymphoplasmacytic lymphoma and explains why previous studies found a high incidence of this lymphoma in CAD ${ }^{6,21}$ However, the histological and immunophenotypic as well as genetic features of CAD differ from those associated with lymphoplasmacytic lymphoma (Table 2). Lymphoplasmacytic lymphoma may show paratrabecular infiltration ${ }^{22}$ and intrasinusoidal infiltration, features not seen in any of the

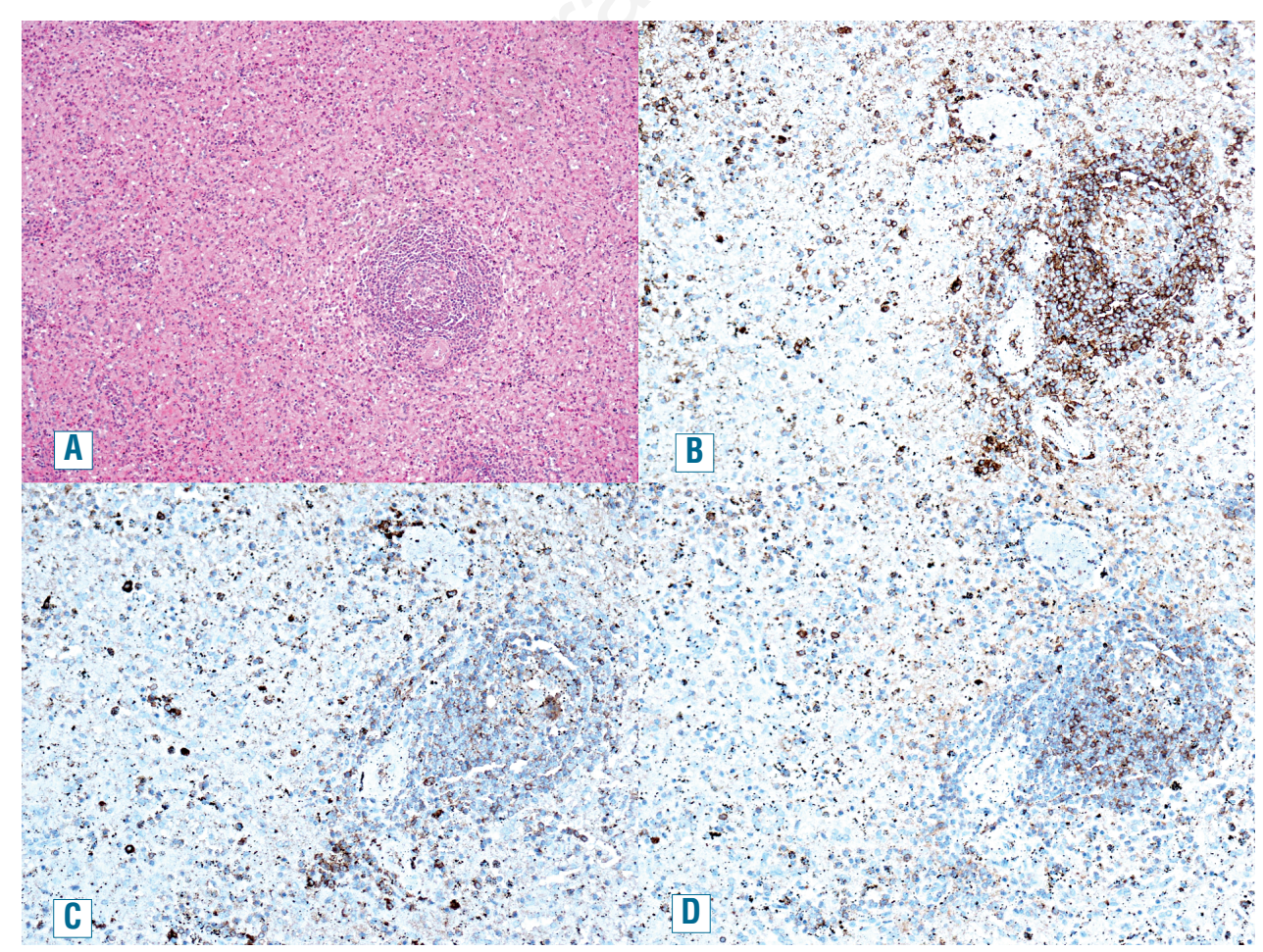

Figure 2. The spleen of patient 4 has a normal red pulp and a rather hypoplastic white pulp [panel (A), H\&E-staining, 40x]. Staining for CD20 highlights the white pulp B lymphocytes. Few $B$ lymphocytes are seen in the red pulp [panel (B), anti-CD20 immunoperoxidase staining, 100X]. Immunoperoxidase staining for IgK [panel (C), 100X] and for IgL [panel (D), 100X] does not show an obvious immunoglobulin light chain restriction in $B$ lymphocytes or plasma cells. 
CAD-associated lymphoid lesions. Importantly, cells with plasma cell differentiation or with cytoplasmic immunoglobulin, so-called lymphoplasmacytoid cells, are typically admixed with the lymphoid proliferation in lymphoplasmacytic lymphoma (Online Supplementary Figure S1). This is not seen in CAD. Instead, bone marrow in $\mathrm{CAD}$ is characterized by intraparenchymatous small lymphoid cell aggregates and scattered diffuse infiltration with mature plasma cells that are typically not admixed with the former. Accordingly, the small lymphoid cells in CAD do not express transcription factors that are important for plasma cell differentiation such as MUM1 (IRF4), XBP1 or BLIMP1. By contrast, these transcription factors and surface markers are, although variably, expressed in lymphoplasmacytoid cells of lymphoplasmacytic lymphoma. ${ }^{23,24}$ Furthermore, the marker CD27 is strongly positive in CAD-associated lymphoproliferative disease but has been variably reported to be positive in lymphoplasmacytic lymphoma. ${ }^{25,26}$ By contrast, CD25 is mostly positive in lymphoplasmacytic lymphoma complicated by Waldenström disease, while this marker is only variably expressed in CAD. ${ }^{26}$ Lymphoplasmacytic lymphoma mostly uses IGHV3 family genes and shows $>5 \%$ somatic hypermutation, whereas the mutation rate in CAD-associated lymphoproliferative disease is lower. ${ }^{16,27,28}$ Importantly, the MYD88 L265P mutation, present in over $90 \%$ of cases of lymphoplasmacytic lymphoma, was not found in any of the CAD samples that were tested in our series. ${ }^{16,17}$

Furthermore, the bone marrow disease in CAD patients is not typical of that seen in other small cell variants of Bcell non-Hodgkin lymphomas such as follicular lymphoma, chronic lymphocytic leukemia and mantle cell lymphoma because cytological and immunophenotypic characteristics typical of these lymphomas are lacking. ${ }^{22}$ Follicular lymphoma most often shows paratrabecular infiltration with cleaved cells that express BCL6 and CD10, features not present in CAD-associated lymphoproliferative disease. Chronic lymphocytic leukemia and mantle cell lymphoma may show nodular as well as diffuse infiltration with small round cells. However, larger paraimmunoblasts are variably seen in the former and

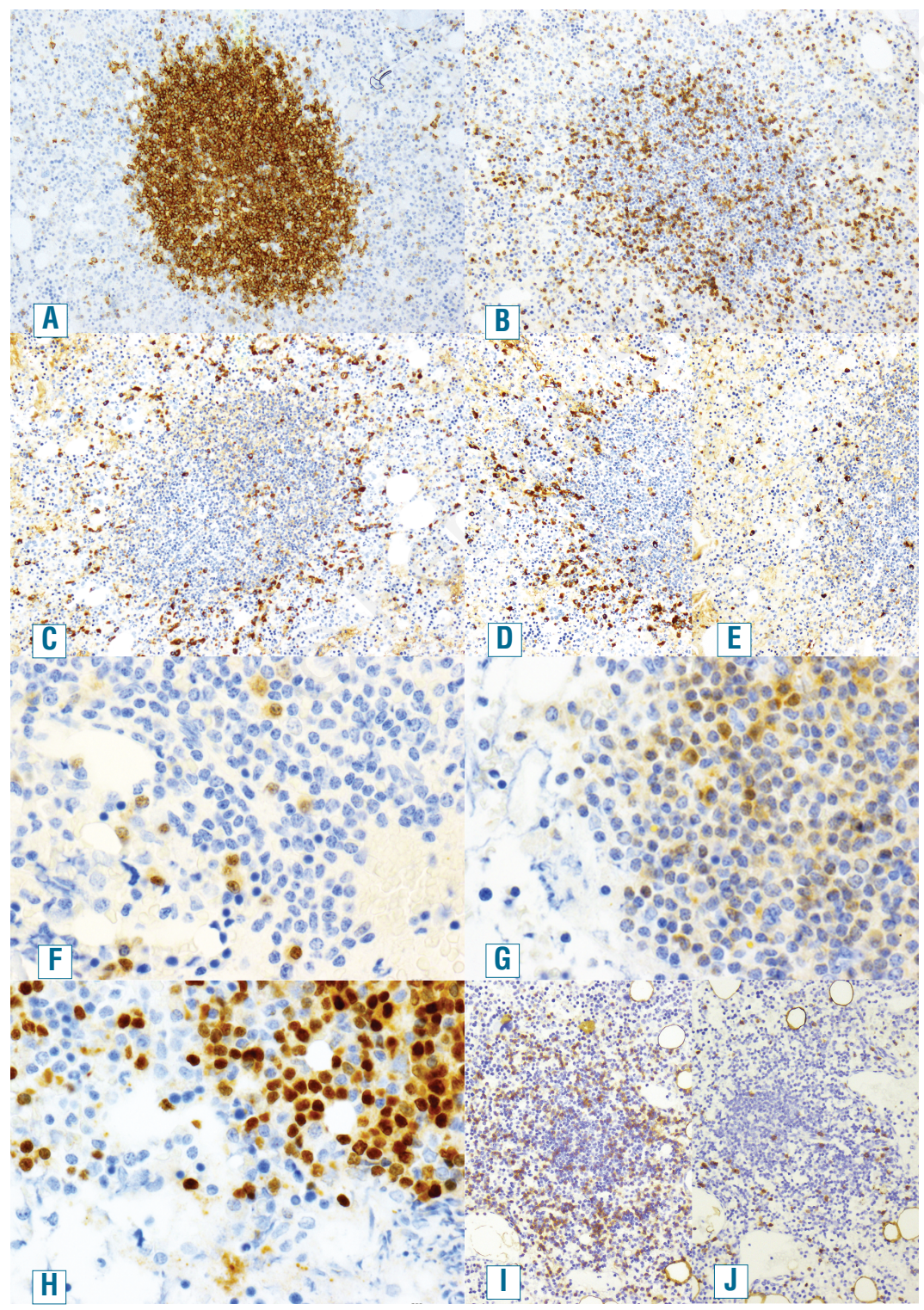

Figure 3. The figure illustrates the immunophenotypic findings in CAD-associated lymphoproliferative disease. The lymphoid nodules consist mainly of $B$ lymphocytes [panel (A), antiCD20 immunoperoxidase staining, 100X] and a moderate amount of $T$ lymphocytes [panel (B), anti-CD3 immunoperoxidase staining, 100X]. Plasma cells are mainly found in the periphery of the nodular infiltrate and the parenchyma and express IgM and IgK [panels (C-E), anti-IgM, anti-IgK and anti-IgL immunoperoxidase staining, respectively, 100X]. Lymphoid cells within the nodular lesions do not express MUM1, but do variably express nuclear BCL10 and strongly express PAX5 [panels (F-H), immunoperoxidase staining, 400X]. T lymphocytes in the lymphoid nodules are mainly CD4 helper cells whereas few CD8 cytotoxic cells are seen [panels (I-J), immunoperoxidase staining for CD4 and CD8, respectively, 100X]. 
cells with slightly cleaved nuclei in the latter, features not seen in CAD patients. Furthermore, chronic lymphocytic leukemia typically co-expresses CD5 and CD23 and weakly CD20 whereas mantle cell lymphoma co-expresses CD5 and cyclin D1, findings not demonstrated in CADassociated lymphoproliferative disease. In conclusion, $\mathrm{CAD}$-associated lymphoproliferative disease does not have features of hitherto well-characterized B-cell nonHodgkin lymphoma types as recognized by the World Health Organization classification of tumors of lymphoid tissues. ${ }^{22}$

Splenic histology, available for two patients with $\mathrm{CAD}$, showed rather limited changes. The white pulp was hypoplastic and contained small B cells without plasma cell

Table 1. Characteristics of the rearranged immunoglobulin heavy chain genes and BCL6 mutational status.

\begin{tabular}{|c|c|c|c|c|c|c|c|c|c|c|}
\hline $\begin{array}{l}\text { Patient } \\
\text { number }\end{array}$ & $\begin{array}{c}\text { IGHV4-34 } \\
\text { homology } \\
(\%)\end{array}$ & J & D & $\begin{array}{l}\text { CDR3 } \\
\text { length }\end{array}$ & & & 3 amino ac & d sequences & & $\begin{array}{c}\text { BCL6 } \\
\text { intron } 1 \\
\text { mutations }\end{array}$ \\
\hline 12 & 98.3 & $J 6-02$ & D6-13 & 29 & AR & GCPPP & PISAAD & TFVESLSCGGL & YYGMDV & - \\
\hline 16 & 94.1 & J4-02 & D6-19 & 15 & AR & PFGKD & SSGWY & VP & Y & - \\
\hline 19 & 93.7 & J4-02 & D3-03 & 14 & $\mathrm{AR}$ & GSSG & FSRG & $\mathrm{L}$ & FDH & - \\
\hline 24 & 98.1 & $J 3-01$ & D3-03 & 19 & AR & YPPA & ITIFGW & I & DAFDV & $\begin{array}{l}122 \mathrm{G} / \mathrm{T} \\
423 \mathrm{C} / \mathrm{G} \\
741 \mathrm{~T} / \mathrm{A}\end{array}$ \\
\hline 26 & 92.5 & $J 5-01$ & D2-21 & 13 & $\mathrm{AR}$ & & YSSGY & FSGG & DY & - \\
\hline 27 & 94.4 & $J 3-01$ & D3-16 & 15 & AR & GA & GEGT & TP & YGMDV & - \\
\hline 29 & 94.7 & J4-02 & D5-12 & 14 & AR & GV & GSSAYDY & VI & $\mathrm{Y}$ & - \\
\hline 34 & 97.2 & $J 4-02$ & $D 6-13$ & 29 & AR & GCPPP & ISAAD & TFVESLSCGGL & YYGMDV & - \\
\hline
\end{tabular}

Table 2. Comparative characteristics of CAD-associated lymphoproliferative disease, lymphoplasmacytic lymphoma and bone marrow infiltration by marginal zone lymphoma.

\begin{tabular}{|c|c|c|c|}
\hline & $\begin{array}{l}\text { CAD-associated } \\
\text { Iymphoproliferative disease }\end{array}$ & $\begin{array}{l}\text { Lymphoplasmacytic } \\
\text { lymphoma }\end{array}$ & $\begin{array}{l}\text { Secondary infiltration } \\
\text { by marginal zone lymphoma }\end{array}$ \\
\hline $\begin{array}{l}\text { Histology } \\
\text { architecture }\end{array}$ & intraparenchymal nodules & $\begin{array}{l}\text { varying degrees of interstitial, } \\
\text { intraparenchymal nodular, } \\
\text { paratrabecular and intra- } \\
\text { sinusoidal infiltration }\end{array}$ & $\begin{array}{l}\text { intraparenchymal nodules } \\
\text { and/or intra-sinusoidal infiltration }\end{array}$ \\
\hline cytological features & $\begin{array}{l}\text { small lymphoid cells with rounded } \\
\text { nuclei, occasional larger cells; } \\
\text { limited diffuse marrow infiltration } \\
\text { with plasma cells that typically are } \\
\text { not admixed with the lymphoid cells }\end{array}$ & $\begin{array}{l}\text { mixed infiltrate with small } \\
\text { lymphocytes, plasmacytoid cells } \\
\text { with occasional Dutcher inclusions } \\
\text { and plasma cells }\end{array}$ & $\begin{array}{l}\text { small to medium sized lymphoid cells } \\
\text { with more abundant, pale cytoplasm; } \\
\text { mostly only few admixed plasma cells }\end{array}$ \\
\hline $\begin{array}{l}\text { Immunophenotype } \\
\text { lymphoid cells }\end{array}$ & $\begin{array}{l}{\mathrm{CD} 20^{+}}, \mathrm{IgKs}^{+} \text {(predominantly), } \\
\mathrm{IgMs}^{+}, \mathrm{IgDs}^{+}, \mathrm{CD}^{2} 7^{+}, \mathrm{CD}^{\prime+}\end{array}$ & $\mathrm{CD}^{2} 0^{+}, \mathrm{IgMs}^{+}, \mathrm{IgDs}^{+}, \mathrm{CD}_{2} 7^{+}, \mathrm{CD}^{-/+}$ & $\mathrm{CD}^{2} 0^{+}, \mathrm{IgMs}^{+}, \mathrm{IgDs}^{+/}, \mathrm{CD} 5$ \\
\hline plasmacytoid cells & & $\mathrm{CD}^{2} 0^{+}, \mathrm{CD} 138, \mathrm{IgMc}^{+}, \operatorname{IgKc}^{+}$(mostly) & - \\
\hline plasma cells & $\begin{array}{l}\mathrm{CD} 20, \mathrm{CD} 138^{+}, \mathrm{IgMc}^{+}, \mathrm{IgKC}^{+} \\
\text {(predominantly) }\end{array}$ & $\begin{array}{l}\mathrm{CD}^{+} 0^{+}, \mathrm{CD} 138, \mathrm{CD} 38^{+}, \mathrm{IgMc}^{+}, \mathrm{IgKC}^{+} \\
\text {(predominantly) }\end{array}$ & - \\
\hline \multicolumn{4}{|l|}{ Genetics } \\
\hline$I G H V$ gene usage & IGHV4-34 (100\%) & $\begin{array}{l}\text { IGHV3 (77\%) with IGHV3-23(35\%) } \\
\text { and IGHV3-7 (29\%) }\end{array}$ & $\begin{array}{l}\text { IGHV1-2 (splenic), IGHV3-4 (nodal), } \\
\text { variable according to site } \\
\text { (extranodal) }\end{array}$ \\
\hline $\begin{array}{l}\text { IG somatic } \\
\text { mutation rate }\end{array}$ & medium $(5 \%)$ & $\operatorname{high}(>5 \%)$ & $\begin{array}{l}\text { variable according to type and site } \\
(5-10 \%)\end{array}$ \\
\hline $\begin{array}{l}\text { MYD88 L265P mutation } \\
\text { IGHV4-34 (100\%) }\end{array}$ & absent & present ( $>90 \%$ of cases) & present ( $\sim 10 \%$ of cases) \\
\hline Putative cell of origin & marginal zone B cell? & post-germinal center B cell & marginal zone B cell \\
\hline $\begin{array}{l}\text { Transformation } \\
\text { to large cell lymphoma }\end{array}$ & no & yes $(5-13 \%)$ & yes (30\%) \\
\hline
\end{tabular}


differentiation. B cells in the white pulp did not show immunoglobulin light chain restriction. Few, scattered monotypic IgM-expressing plasma cells were seen in the red pulp. Apart from the latter, the splenic red pulp did not show other evidence of aberrant lymphoid cell infiltration. Thus, the histological findings in CAD differ from those found in splenic involvement with known B-cell nonHodgkin lymphoma types that typically show involvement and expansion of the white pulp, or less often of the red pulp. Of interest, monotypic plasma cells were rather few in the spleen indicating that the bone marrow is the predominant source of monoclonal IgM production in CAD.

The extent of bone marrow infiltration does not correlate well with the severity of anemia as indicated by a non-significant Spearman rank correlation coefficient $\left(\mathrm{r}_{\mathrm{s}}=\right.$ -0.24). This is not surprising since the thermal amplitude of the secreted IgM has previously been shown to be the most important factor determining the severity of anemia. ${ }^{2,9}$ In addition, the amount of hexameric versus pentameric IgM produced by CAD-associated lymphoproliferative disease might also determine the severity of anemia. ${ }^{10}$ Hexameric IgM lacks J chain and is highly complement-activating thus resulting in increased red blood cell lysis. Of interest, no abnormal bone marrow infiltration with B cells was detected in the biopsies of $14 / 54$ patients, despite a clinically established diagnosis of CAD and a monoclonal B-cell population proven by flow cytometry in the four patients analyzed. Sampling error or minimal bone marrow disease with secretion of highly lytic antibodies might explain this finding.

Waldenström macroglobulinemia is a clinical entity defined by lymphoplasmacytic lymphoma in the bone marrow and monoclonal IgM in serum..$^{29}$ Many patients with CAD have, therefore, previously been classified as having Waldenström macroglobulinemia. ${ }^{30}$ Based on the findings presented in the current study, patients with CAD should not be included with true Waldenström macroglobulinemia. A minority of CAD patients show no obvious bone marrow lymphoproliferative disease. We suggest that the latter patients be diagnosed clinically as having an IgM-related disorder. This is defined as a clinical condition mediated by monoclonal IgM without evidence of lymphoma. ${ }^{31}$ However, patients without obvious bone marrow disease probably represent one end of the spectrum seen in CAD rather than having a distinct disease. ${ }^{5}$ This is supported by our previous findings that the extent of bone marrow involvement does not correlate with response to B-cell directed therapy. ${ }^{14,15}$

Monoclonal IGHV4-34 gene rearrangement is a welldescribed finding in $\mathrm{CAD}$ and was also detected in our patients. ${ }^{12}$ The framework region 1 (FR1) of the IGHV4-34 gene segment determines anti-I specificity. ${ }^{32}$ In particular, amino acid residues 7 and 23-25 determine this specificity and are conserved in $\mathrm{CAD}$ despite the fact that most rearranged immunoglobulin genes show somatic hypermutation..$^{33,34}$ The latter was also found in our cases. In addition to FR1, crystallography has indicated that the exposed C-terminal flanking region but not the antigenbinding pocket site of CDR3 is also important for binding to I-antigen. ${ }^{35}$ The antigen-binding pocket site of the antibody may, therefore, bind to another additional antigen. The latter may be heterogeneous in CAD as indicated by variable CDR3 regions without obvious sequence motifs, except for the absence of positively charged amino acids, as shown in our study and in other studies. ${ }^{12,20}$ Of interest, two patients in our series had identical and exceptionally long CDR3 regions. The significance of this is not clear. These CDR3 sequences had not been found in earlier series and it therefore remains unclear whether this particular sequence is of more general importance for clonal selection by a specific antigen in $\mathrm{CAD}$.

The intermediate level of $\mathrm{IgH}$ gene mutation associated with the low level or absence of BCL6 mutation is similar to what has been reported for marginal zone B-cell lymphoma. ${ }^{36}$ The absence of mutations in BCL6, a gene highly expressed in germinal center $B$ cells and hence also affected by somatic hypermutation in those cells, is an argument in favor of the origin of the clonal B cells in CAD being $B$ cells that have acquired somatic hypermutation without passing through the germinal center. ${ }^{37}$ Of interest, normal IGHV4-34-expressing B cells home with preference to the splenic marginal zone and are not normally recruited to the germinal center, except in auto-immune diseases such as lupus erythematosus. ${ }^{38}$ An origin from marginal zone B cells is further supported by the CD27+, $\mathrm{IgM}^{+}$and $\mathrm{IgD}^{+}$immunophenotype of CAD-associated lymphoproliferative disease. Since secondary lymphoid tissue involvement is not a feature of CAD-associated lymphoproliferative disorder, an origin from immature or transitional B-cell precursors of IGHV4-34-expressing marginal zone $\mathrm{B}$ cells in the bone marrow might be postulated. Such an origin might not be in contradiction with the presence of immunoglobulin somatic hypermutation in CAD-associated lymphoproliferative disease. Somatic mutations in immature or transitional $B$ cells may be part of a pre-immune diversification of $B$ cells as indicated by data from patients with hyper-IgM syndrome who lack germinal centers. ${ }^{39,40}$ Alternatively, CAD-associated lymphoproliferative disease may arise from IGHV4-34expressing circulating marginal zone B cells that, for unknown reasons, have homed to the bone marrow.

In conclusion, by studying the bone marrow of a large series of patients with primary CAD, we have provided arguments for an underlying primary bone marrow B-cell lymphoproliferative disease with unique pathological and genetic features that distinguish the disease from wellcharacterized B-cell lymphoma types. Of interest, trisomy of chromosome 3q11-q29 is a common feature of the four cases hitherto described, ${ }^{41,42}$ although all cases show additional unique changes. These recurrent genetic changes support the notion that $\mathrm{CAD}$-associated lymphoproliferative disease is a distinct entity. A more extensive genetic analysis is needed to clarify the molecular basis of the disease.

\section{Acknowledgments}

The authors would like to thank Ellen Hellesylt at the Department of Pathology, The Norwegian Radium Hospital, for excellent help with immunohistochemical staining.

\section{Funding}

This study was supported by a grant from the Norwegian Cancer Society.

\section{Authorship and Disclosures}

Information on authorship, contributions, and financial \& other disclosures was provided by the authors and is available with the online version of this article at www. haematologica.org. 


\section{References}

1. Dacie SJ. The immune haemolytic anaemias: a century of exciting progress in understanding. Br J Haematol. 2001;114(4): 770-85.

2. Rosse WF, Adams JP. The variability of hemolysis in the cold agglutinin syndrome. Blood. 1980;56(3):409-16.

3. Rosse WF Hillmen P, Schreiber AD. Immunemediated hemolytic anemia. Hematology Am Soc Hematol Educ Program. 2004;48-62.

4. Issitt PD. I blood group system and its relationship to disease. J Med Lab Technol. 1968;25(1):1-6

5. Berentsen S, Tjonnfiord GE. Diagnosis and treatment of cold agglutinin mediated autoimmune hemolytic anemia. Blood Rev. 2012;26(3):107-15.

6. Berentsen S, Ulvestad E, Langholm R, Beiske $\mathrm{K}$, Hjorth-Hansen H, Ghanima W, et al. Primary chronic cold agglutinin disease: a population based clinical study of 86 patients. Haematologica. 2006;91(4):460-6.

7. Michel M. Classification and therapeutic approaches in autoimmune hemolytic anemia: an update. Expert Rev Hematol. 2011:4(6):607-18.

8. Berentsen S, Beiske K, Tjonnfjord GE. Primary chronic cold agglutinin disease: an update on pathogenesis, clinical features and therapy. Hematology. 2007;12(5):361-70

9. Dacie JV. Auto-immune haemolytic anaemia (AIHA): cold antibody syndromes I: idiopathic types: clinical presentation and haematological findings. In: Dacie JV, editor. The Haemolytic Anaemias. Churchill Livingstone; 1992. p. 210-39.

10. Hughey CT, Brewer JW, Colosia AD, Rosse WF, Corley RB. Production of IgM hexamers by normal and autoimmune B cells: implications for the physiologic role of hexameric IgM. J Immunol. 1998:161(8):4091-7.

11. Zilow G, Kirschfink M, Roelcke D. Red-cell destruction in cold agglutinin disease. Infusionsther Transfusionsmed 1994;21(6): 410-5.

12. Pascual V, Victor K, Spellerberg M, Hamblin T], Stevenson FK, Capra JD. VH restriction among human cold agglutinins. The VH4-21 gene segment is required to encode anti-I and anti-i specificities. J Immunol. 1992;149 (7):2337-44.

13. Bhat NM, Bieber MM, Spellerberg MB, Stevenson FK, Teng NN. Recognition of autoand exoantigens by V4-34 gene encoded antibodies. Scand J Immunol. 2000;51(2): 134-40.

14. Berentsen S, Ulvestad E, Gjertsen BT, Hjorth-Hansen H, Langholm R, Knutsen H, et al. Rituximab for primary chronic cold agglutinin disease: a prospective study of 37 courses of therapy in 27 patients. Blood. 2004;103(8):2925-8

15. Berentsen S, Randen U, Vagan AM, HjorthHansen H, Vik A, Dalgaard J, et al. High response rate and durable remissions following fludarabine and rituximab combination therapy for chronic cold agglutinin disease. Blood. 2010;116(17):3180-4.

16. Gachard N, Parrens M, Soubeyran I, Petit B, Marfak A, Rizzo D, et al. IGHV gene features and MYD88 L265P mutation separate the three marginal zone lymphoma entities and Waldenstrom macroglobulinemia/lymphoplasmacytic lymphomas. Leukemia. 2013;27(1):183-9.

17. Treon SP, Xu L, Yang G, Zhou Y, Liu X, Cao $Y$, et al. MYD88 L265P somatic mutation in Waldenstrom's macroglobulinemia. N Engl J Med. 2012;367(9):826-33

18. Sanchez ML, Almeida J, Vidriales B, Lopez Berges MC, Garcia-Marcos MA, Moro MJ, et al. Incidence of phenotypic aberrations in a series of 467 patients with B chronic lymphoproliferative disorders: basis for the design of specific four-color stainings to be used for minimal residual disease investigation. Leukemia. 2002;16(8):1460-9.

19. van Dongen JJ, Lhermitte L, Bottcher S, Almeida J, van dV, V, Flores-Montero J, et al. EuroFlow antibody panels for standardized n-dimensional flow cytometric immunophenotyping of normal, reactive and malignant leukocytes. Leukemia. 2012;26(9):1908-75

20. Spellerberg M, Chapman C, Hamblin T, Stevenson F. Dual recognition of lipid A and DNA by human antibodies encoded by the VH4-21 gene. A possible link between infection and lupus. Ann NY Acad Sci. 1995; 764:427-32.

21. Zhang QY, Foucar K. Bone marrow involvement by Hodgkin and non-Hodgkin lymphomas. Hematol Oncol Clin North Am. 2009;23(4):873-902 .

22. Swerdlow $\mathrm{SH}$. WHO Classification of Tumours of Haematopoietic and Lymphoid tissue. Lyon: IARC; 2008

23. Leleu X, Hunter ZR, Xu L, Roccaro AM, Moreau AS, Santos DD, et al. Expression of regulatory genes for lymphoplasmacytic cell differentiation in Waldenstrom macroglobulinemia. Br J Haematol. 2009;145 (1):59-63.

24. Natkunam Y, Warnke RA, Montgomery K, Falini B, van De RM. Analysis of MUM1/IRF4 protein expression using tissue microarrays and immunohistochemistry. Mod Pathol. 2001:14(7):686-94

25. Kriangkum J, Taylor BJ, Treon SP, Mant MJ, Belch AR, Pilarski LM. Clonotypic IgM $\mathrm{V} / \mathrm{D} / \mathrm{J}$ sequence analysis in Waldenstrom macroglobulinemia suggests an unusual Bcell origin and an expansion of polyclonal $\mathrm{B}$ cells in peripheral blood. Blood. 2004;104 (7):2134-42

26. San Miguel JF, Vidriales MB, Ocio E, Mateo G, Sanchez-Guijo F, Sanchez ML, et al. Immunophenotypic analysis of Waldenstrom's macroglobulinemia. Semin Oncol. 2003;30(2):187-95.

27. Martin-Jimenez P, Garcia-Sanz R, Balanzategui A, Alcoceba M, Ocio E, Sanchez ML et al. Molecular characterization of heavy chain immunoglobulin gene rearrangements in Waldenström's macroglobulinemia and IgM monoclonal gammopathy of undetermined significance. Haematologica. 2007;92:635-642.

28. Varettoni M, Zibellini S, Capello D, Arcaini L, Rossi D, Pascutto C et al. Clues to pathogenesis of Waldenström macroglobulinemia and immunoglobulin $\mathrm{M}$ monoclonal gammopathy of undetermined significance provided by analysis of immunoglobulin heavy chain gene rearrangement and clustering of B-cell receptors. Leuk Lymphoma. 2013;54 (11):2485-9.
29. Owen RG. Developing diagnostic criteria in Waldenstrom's macroglobulinemia. Semin Oncol. 2003;30(2):196-200.

30. Berentsen S. Cold agglutinin-mediated autoimmune hemolytic anemia in Waldenström's macroglobulinemia. Clin Lymphoma Myeloma. 2009;9(1):110-2.

31. Cesana C, Barbarano L, Miqueleiz S, Lucchesini C, Ricci F, Varettoni $M$ et al. Clinical characteristics and outcome of immunoglobulin M-related disorders. Clin Lymphoma. 2005;5(4):261-4.

32. Potter KN. Molecular characterization of cold agglutinins. Transfus Sci. 2000;22(12):113-9.

33. Pascual V, Victor K, Lelsz D, Spellerberg MB, Hamblin TJ, Thompson KM, et al Nucleotide sequence analysis of the $\mathrm{V}$ regions of two IgM cold agglutinins. Evidence that the VH4-21 gene segment is responsible for the major cross-reactive idiotype. J Immunol. 1991;146(12):4385-91.

34. Silberstein LE, Jefferies LC, Goldman J, Friedman D, Moore JS, Nowell PC, et al. Variable region gene analysis of pathologic human autoantibodies to the related $i$ and red blood cell antigens. Blood. 1991;78(9): 2372-86.

35. Potter KN, Hobby P, Klijn S, Stevenson FK, Sutton BJ. Evidence for involvement of a hydrophobic patch in framework region 1 of human V4-34-encoded Igs in recognition of the red blood cell I antigen. J Immunol. 2002;169(7):3777-82.

36. Traverse-Glehen A, Verney A, Baseggio L, Felman P, Callet-Bauchu E, Thieblemont C, et al. Analysis of BCL-6, CD95, PIM1, RHO/TTF and PAX5 mutations in splenic and nodal marginal zone B-cell lymphomas suggests a particular B-cell origin. Leukemia. 2007:21(8):1821-4

37. Seifert M, Kuppers R. Molecular footprints of a germinal center derivation of human $\mathrm{IgM}+(\mathrm{IgD}+) \mathrm{CD} 27+\mathrm{B}$ cells and the dynamics of memory B cell generation. J Exp Med. 2009;206(12):2659-69

38. Milner EC, Anolik J, Cappione A, Sanz I. Human innate B cells: a link between host defense and autoimmunity? Springer Semin Immunopathol. 2005;26(4):433-52.

39. Kuraoka M, Liao D, Yang K, Allgood SD, Levesque MC, Kelsoe G, et al. Activationinduced cytidine deaminase expression and activity in the absence of germinal centers: insights into hyper-IgM syndrome. Immunol. 2009:183(5):3237-48.

40. Weller S, Braun MC, Tan BK, Rosenwald A, Cordier C, Conley ME, et al. Human blood IgM "memory" B cells are circulating splenic marginal zone $\mathrm{B}$ cells harboring a prediversified immunoglobulin repertoire. Blood. 2004:104(12):3647-54.

41. Chng WJ, Chen J, Lim S, Chong SM, Kueh YK, Lee SH. Translocation (8;22) in cold agglutinin disease associated with B-cell lymphoma. Cancer Genet Cytogenet. 2004;152(1):66-9.

42. Michaux L, Dierlamm J, Wlodarska L, Criel A, Louwagie A, Ferrant A, et al. Trisomy 3q11-q29 is recurrently observed in B-cell non-Hodgkin's lymphomas associated with cold agglutinin syndrome. Ann Hematol. 1998;76(5):201-4. 